\title{
Experimental study of heat pump type air-water for heating system performance
}

\author{
Penka Zlateva ${ }^{1, *}$, Krastin Yordanov $^{1}$ \\ ${ }^{1}$ Department of Thermal Engineering, Shipbuilding Faculty, Technical University of Varna, 1 \\ Studentska Str., 9010 Varna, Bulgaria
}

\begin{abstract}
The operation of an air-to-water heat pump system providing space heating production for an administrative building in Varna has been explored. For this purpose, discontinuous operational mode of the heat pump system during wintertime is considered. Study has been performed by use of real values for external ambient temperature and operating characteristics of the heat pump system. The seasonal efficiency of the heat pump operation has been calculated. Also, the minimal external ambient temperature until the heat pump may work in heating regime and operation duration at outdoor air temperatures higher than the design air temperature can be determined. The economic analysis of the heat pump system exploitation has been made finally.
\end{abstract}

\section{Introduction}

Demand for environmental solutions for building heating is growing up. It is caused by both global warming and uncertainty about electrical energy prices. Heat pump systems use electricity for their work, and some of this electricity comes from renewable sources [1-2]. This makes them both effective for well-known environmental issues related to direct and indirect emissions of carbon dioxide in the atmosphere, and efficient for heating and cooling. Moreover, they satisfy both consumers' expectations of both quality and cost effectiveness [3-4]. The ever-increasing energy consumption of buildings has caused a great interest in improving the seasonal characteristics of heat pumps [5-6]. Also, the temperature of the outside air, which has a great impact on the heating characteristics of the heat pump, is also essential. Northeastern Bulgaria with its Black Sea climate, gives the possibility of maximum efficiency of the heat pump systems, in particular air-water. As known, the use of outside air is to heat the water through the heat pump to which the heaters are powered. An important point in the investigation of energy efficiency buildings is the precise operation of the heat source and the determination of its operating efficiency for the entire heating season. In the present work calculations are made, which aim to determine the efficiency of the air-to-water heat pump heating system.

\footnotetext{
* Corresponding author: pzlateva@tu-varna.bg
} 


\section{Presentation}

This paper presents the results of a methodology [7], which determines the operational seasonal efficiency of an air-water heat pump system used for heating an administrative building located in Varna. During the winter heating season, the building is heated with the Wesper (Systemair) model VLH $804 \mathrm{LN}$ with discontinuous operation. The operating schedule of the air-water heating system for heating is from Monday to Friday from 6 a.m. to 6 p.m. An important point for the accuracy of the calculations is to obtain accurate information about the change in external ambient temperature over time. For the external ambient temperature in the survey used data measured in 5 minutes and obtained from a meteorological station of the National Institute of Meteorology and Hydrology-Varna for the heating season from 29.10.2017 to 19.04.2018, fig.1 [8].

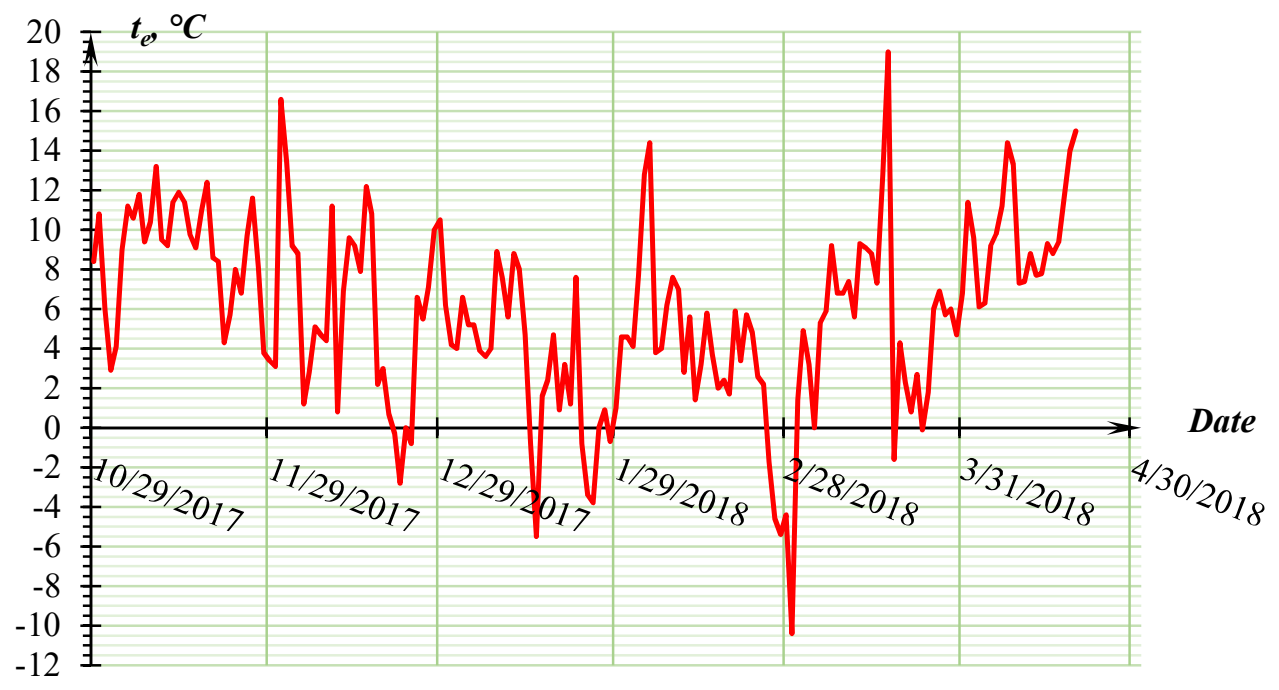

Fig. 1. Graph of external ambient temperature for the period from 29.10.2017 to 19.04.2018

Also, from fig. 1 for the heating season (from 29.10.2017 to 19.04.2018) the number of hours during the heating season in which the external ambient temperature is in the i-th interval [7] shown in Table 1 by months is calculated.

Table 1. Calculated counts of hours by months during the heating season and their total sum for the $i$-th interval

\begin{tabular}{|c|c|c|c|c|c|c|c|c|}
\hline \multirow{2}{*}{$\begin{array}{c}\boldsymbol{t}_{\boldsymbol{e}} \\
{ }^{\circ} \mathrm{C}\end{array}$} & \multicolumn{7}{|c|}{$\tau, h$} & \multirow{2}{*}{$\begin{array}{c}\tau_{i} \\
h\end{array}$} \\
\hline & 29.10 .2017 & 11.2017 & 12.2017 & 01.2018 & 02.2018 & 03.2018 & 19.04 .2018 & \\
\hline-5 & 0,0 & 0,00 & 0,00 & 0,83 & 13,67 & 0,50 & 0,00 & 15,00 \\
\hline$\ldots$ & $\ldots$ & $\ldots$ & $\ldots$ & $\ldots$ & $\ldots$ & $\ldots$ & $\ldots$ & $\ldots$ \\
\hline 0 & 0,0 & 0,00 & 3,17 & 17,50 & 2,00 & 29,67 & 0,00 & 52,33 \\
\hline 1 & 0,0 & 0,0 & 10,8 & 14,8 & 2,7 & 7,7 & 0,0 & 36,00 \\
\hline$\ldots$ & $\ldots$ & $\ldots$ & $\ldots$ & $\ldots$ & $\ldots$ & $\ldots$ & $\ldots$ & $\ldots$ \\
\hline 15 & 0,0 & 13,0 & 8,7 & 1,0 & 1,8 & 7,3 & 15,5 & 47,33 \\
\hline$\ldots$ & $\ldots$ & $\ldots$ & $\ldots$ & $\ldots$ & $\ldots$ & $\ldots$ & $\ldots$ & $\ldots$ \\
\hline 19 & 0,0 & 1,2 & 0,0 & 0,0 & 0,0 & 3,0 & 3,5 & 7,67 \\
\hline & & & & & & & $\Sigma \tau_{i}=$ & 1475,33 \\
\hline
\end{tabular}


In fig. 2 is the graphical dependence of the external ambient temperature $\left(t_{e}\right)$ on the number of hours during the heating season $\left(\tau_{i}\right)$ and the number of hours during which the heat pump operates $\left(\tau_{w, i-H P}\right)$.

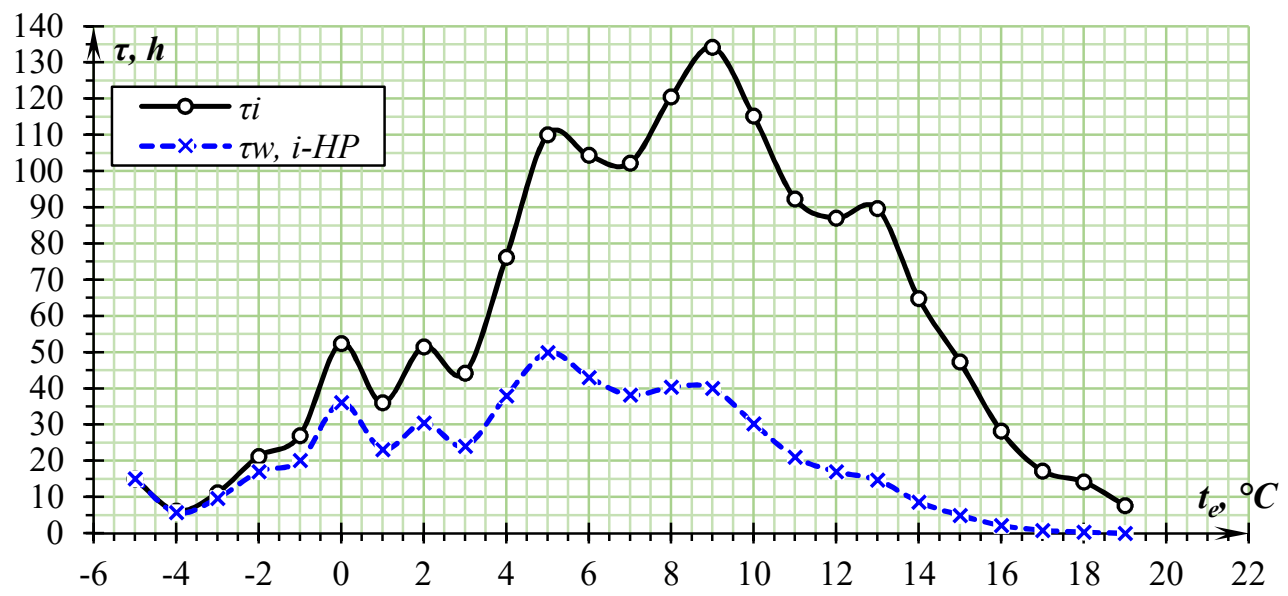

Fig. 2. Graphical dependence of external ambient temperature $\left(t_{e}\right)$ on the number of hours during the heating season $\left(\tau_{i}\right)$ and the number of hours the heat pump operates $\left(\tau_{w, i-H P}\right)$

\section{Methodology for calculation of electrical energy consumed by the heat pump system and seasonal work efficiency}

The methodology for calculating the electrical energy consumption of the heat pump system and the seasonal efficiency of the operation includes the following steps:

1) Price per $1 \mathrm{kWh}$ of electrical energy consumed $E_{p}=0,117 € / k W h$ [9-10];

2) Calculation of heat quantity $Q_{B, i}$ produced for the i-th temperature range, $k W h$

$$
Q_{B, i}=\Phi_{B, i} \cdot \tau_{i}, k W h
$$

where: $\Phi_{B, i}$ - the required heat capacity of the building for the i-th temperature range, $\mathrm{kW}$;

3) Calculation of $\tau_{w, i-H P}$ - the number of hours the heat pump works to produce the required heat for the building, $h[1]$;

$$
\tau_{w, i-H P}=\frac{Q_{B, i}}{Q_{H P}}, h
$$

4) Calculation of $E_{C, i-H P}$ - consumed electrical energy from compressors of the heat pump system for the i-th temperature range, $k W h$;

$$
E_{C, i-H P}=W_{c} \cdot \tau_{w, i-H P}, k W h
$$

5) Calculation of $E_{F, i-H P}$ - consumed electrical energy from fans of the heat pump for the i-th temperature range, $k W h$;

$$
E_{F, i-H P}=W_{F} \cdot \tau_{w, i-H P}, k W h
$$

6) Calculation of $E_{B, i-H P}$ - electrical energy consumption of the building by compressors and fans of the thermo-pump system for the i-th temperature range, $k W h$;

$$
E_{B, i-H P}=E_{C, i-H P}+E_{F, i-H P}, k W h
$$


7) The seasonal coefficient of performance is presented in two temperature ranges:

- $\quad$ from $-5^{\circ} \mathrm{C}$ to $+15^{\circ} \mathrm{C}$

$$
\operatorname{COP}_{-5^{\circ} \mathrm{C}+15^{\circ} \mathrm{C}}=\frac{\sum_{i=-5^{\circ} \mathrm{C}}^{15^{\circ} \mathrm{Q}} Q_{B, i}}{\sum_{i=-5^{\circ} \mathrm{C}}^{15^{\circ} E_{B, i-H P}}}
$$

- $\quad$ from $-5^{\circ} \mathrm{C}$ to $+19^{\circ} \mathrm{C}$

$$
\operatorname{COP}_{-5^{\circ} \mathrm{C}+19^{\circ} \mathrm{C}}=\frac{\sum_{i=-5^{\circ} \mathrm{C}}^{19^{\circ} \mathrm{C}} Q_{B, i}}{\sum_{i=-5^{\circ} \mathrm{C}}^{19^{\circ} E_{B, i-H P}}}
$$

8) The calculated value for the consumed electrical energy for the i-th temperature interval is presented in the equation:

$$
\text { PriceE } E_{H P}=E_{B, i-H P} \cdot E_{p}, €
$$

From the catalog of Wesper (Sistemair) model VLH 804 LN [11] has taken the data of the heating capacity $\left(Q_{H P}\right)$ and the electrical power of the compressors $\left(P_{C}\right)$ as a function of the external ambient temperature $\left(t_{e}\right)$ and the temperature of supply water to the building $\left(t_{S W}\right)$.

At external ambient temperature of $0^{\circ} \mathrm{C}$ and above, the heating water produced by the heat pump is at a temperature of $+50^{\circ} \mathrm{C}$. When the external ambient temperature is less than $0^{\circ} \mathrm{C}$ and higher than $-5^{\circ} \mathrm{C}$, the heat pump produces water for heating at $+45^{\circ} \mathrm{C}$.

The electrical power of the compressors $\left(P_{C}\right)$ and the fans $\left(P_{F}\right)$ is equal to the work performed $W_{c}$ and $W_{F}$ or:

$P_{F}=W_{F}=3 u l x 1,25 \mathrm{~kW}=3,75 \mathrm{~kW}$

$P_{C}=W_{c}$ - Table 2

Table 2 shows the flow heat capacity $\left(Q_{H P}\right)$ and the operation of compressors $\left(W_{C}\right)$ at external ambient temperature $\left(t_{e}\right)$ ranging from $-5^{\circ} \mathrm{C}$ to $19^{\circ} \mathrm{C}$ on the Wesper VLH $804 \mathrm{LN}$ heat pump and the supply water temperature to building $\left(t_{S W}\right)-+45^{\circ} \mathrm{C}$ and $+50^{\circ} \mathrm{C}$. Yellow values are given after heat capacity interpolation $\left(Q_{H P}\right)$ and the operation of compressors $\left(W_{C}\right)$ depending on the external ambient temperature $\left(t_{e}\right)$ - Fig. 2 and Fig. 3.

Table 2. Flow heating capacity $\left(Q_{H P}\right)$ and the operation of the compressors $\left(W_{C}\right)$ when the external

\begin{tabular}{|c|c|c|c|c|c|c|c|}
\hline $\begin{array}{c}\boldsymbol{t}_{\boldsymbol{e}} \\
{ }^{\circ} \mathrm{C}\end{array}$ & $\begin{array}{c}t_{S W} W \\
{ }^{\circ} \mathrm{C}\end{array}$ & $\begin{array}{l}Q_{H P} \\
k W\end{array}$ & $\begin{array}{l}W_{C} \\
\boldsymbol{k} \boldsymbol{W}\end{array}$ & $\begin{array}{c}\boldsymbol{t}_{\boldsymbol{e}} \\
{ }^{\circ} \mathrm{C}\end{array}$ & $\begin{array}{c}t_{S W} W \\
{ }^{\circ} \mathrm{C}\end{array}$ & $\begin{array}{l}Q_{H P} \\
k W\end{array}$ & $\begin{array}{l}W_{C} \\
k W\end{array}$ \\
\hline-5 & \multirow{6}{*}{45} & 159,1 & 65,20 & 8 & \multirow{12}{*}{50} & 218,6 & 71,33 \\
\hline-4 & & 164,2 & 63,38 & 9 & & 223,2 & 71,47 \\
\hline-3 & & 169,2 & 62,20 & 10 & & 227,9 & 71,60 \\
\hline-2 & & 174,0 & 62,00 & 11 & & 233,0 & 71,76 \\
\hline-1 & & 178,7 & 62,22 & 12 & & 238,1 & 71,92 \\
\hline 0 & & 183,5 & 62,40 & 13 & & 243,1 & 72,08 \\
\hline 1 & \multirow{7}{*}{50} & 186,3 & 70,68 & 14 & & 248,2 & 72,24 \\
\hline 2 & & 191,0 & 70,76 & 15 & & 253,3 & 72,40 \\
\hline 3 & & 195,8 & 70,84 & 16 & & 259,1 & 72,57 \\
\hline 4 & & 200,5 & 70,92 & 17 & & 264,9 & 72,75 \\
\hline 5 & & 205,3 & 71,00 & 18 & & 271,0 & 72,93 \\
\hline 6 & & 209,6 & 71,10 & 19 & & 277,3 & 73,12 \\
\hline 7 & & 213,9 & 71,20 & - & - & - & - \\
\hline
\end{tabular}
ambient temperature $\left(t_{e}\right)$ in the range from $-5^{\circ} \mathrm{C}$ to $19^{\circ} \mathrm{C}$ in the heat pump Wesper VLH $804 \mathrm{LN}$ and temperature of supply water to the building $\left(t_{S W}\right)-+45^{\circ} \mathrm{C}$ and $+50^{\circ} \mathrm{C}$ 
The data from Table 2 shows the graphical dependence of the supplied heat capacity $\left(Q_{H P}\right)$ on the external ambient temperature $\left(t_{e}\right)$ from $-5^{\circ} \mathrm{C}$ to $+19^{\circ} \mathrm{C}$ on the Wesper VLH $804 \mathrm{LN}$ Heat Pump $\left(t_{S W}\right)-+45^{\circ} \mathrm{C}$ and $+50^{\circ} \mathrm{C}$, shown in Figure 3.

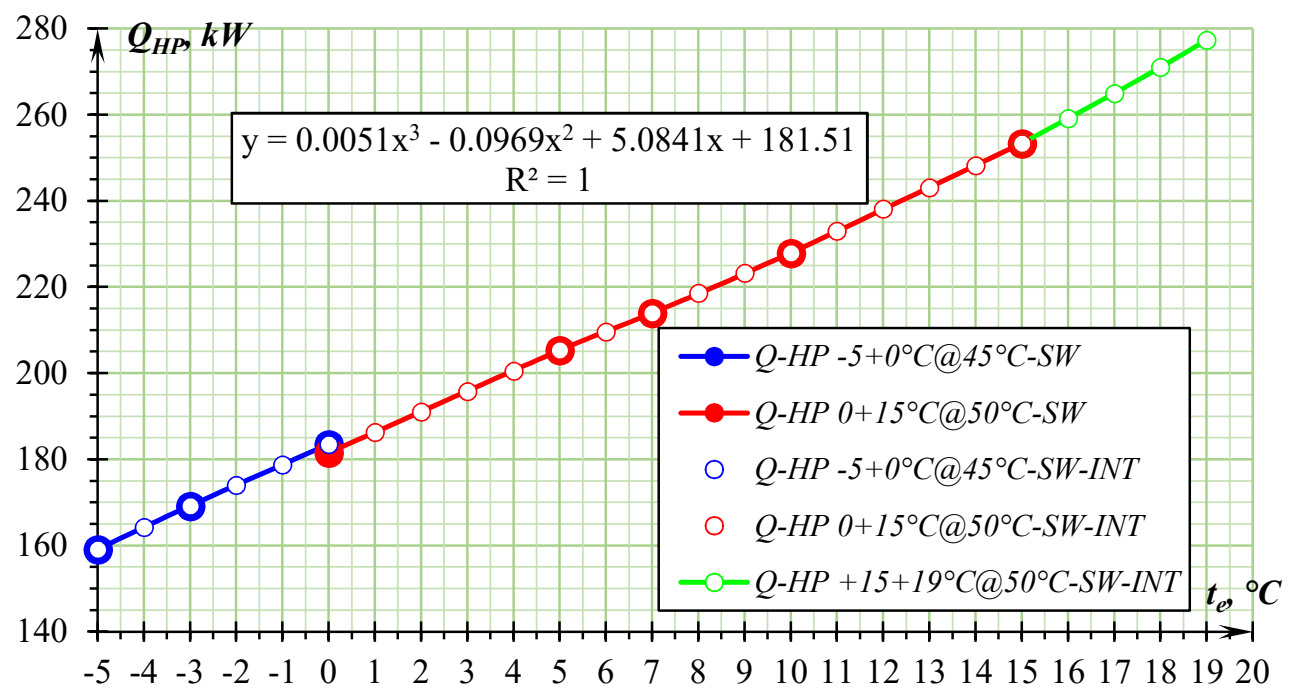

Fig. 3. Heat pump capacity $\left(Q_{H P}\right)$ and the external ambient temperature $\left(t_{e}\right)$ temperature range from $5^{\circ} \mathrm{C}$ to $+19^{\circ} \mathrm{C}$ on heat pump Wesper VLH $804 \mathrm{LN}$ at the temperature of the water supplied to the building $\left(t_{S W}\right)-+45^{\circ} \mathrm{C}$ and $+50^{\circ} \mathrm{C}$

Table 2 shows the graphical dependence of the compressed air heat capacity $\left(W_{C}\right)$ from the external ambient temperature $\left(t_{e}\right)$ at $-5^{\circ} \mathrm{C}$ to $+19^{\circ} \mathrm{C}$ on the Wesper VLH $804 \mathrm{LN}$ heat pump when delivering water to the building $\left(t_{S W}\right)-+45^{\circ} \mathrm{C}$ and $+50^{\circ} \mathrm{C}$, shown in Figure 4 .

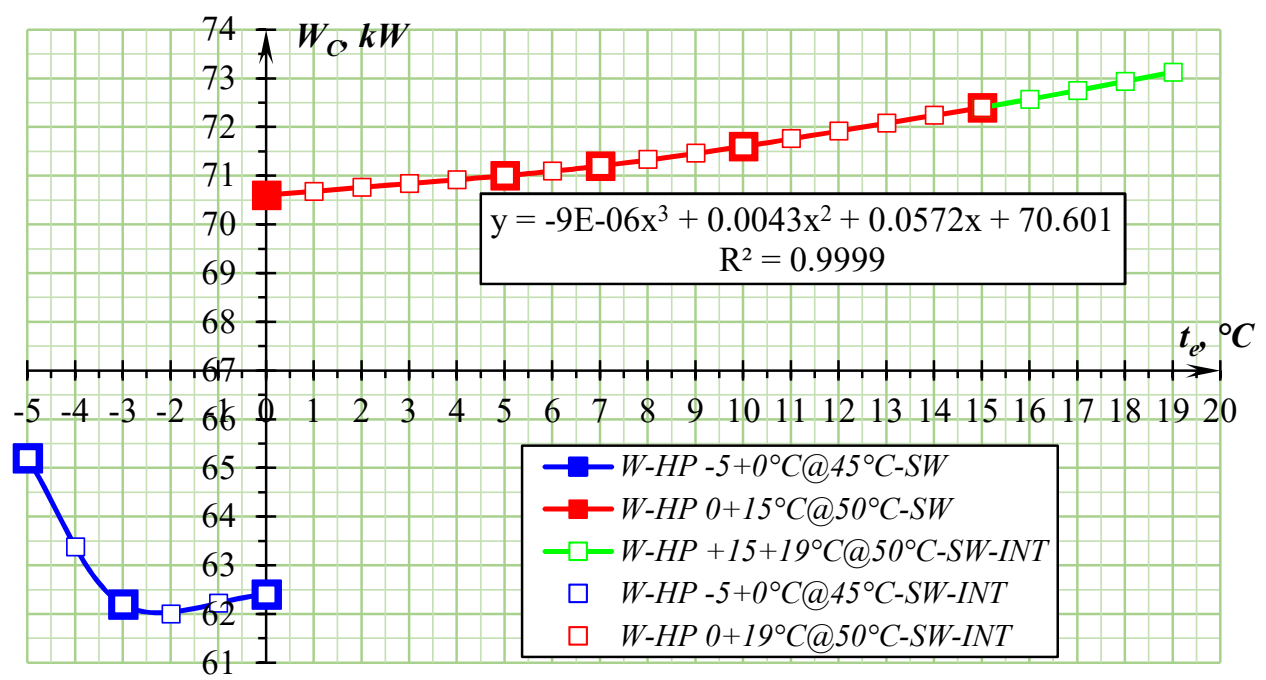

Fig.4. Graph of the heat capacity of the compressors $\left(W_{C}\right)$ and the external ambient temperature $\left(t_{e}\right)$ in the range of $-5^{\circ} \mathrm{C}$ to $+19^{\circ} \mathrm{C}$ on the Wesper VLH $804 \mathrm{LN}$ at the temperature of the water supplied to the building $\left(t_{S W}\right)-+45^{\circ} \mathrm{C}$ and $+50^{\circ} \mathrm{C}$ 


\section{Results and analysis}

The results of the method calculations are given in Table 3 and shown graphically in Figure 5.

Table 3. Calculation of the thermal energy for the building $\left(Q_{B, i}\right)$, the consumption of the electrical energy consumption $\left(E_{B, i-H P}\right)$ and its value (Price $\left.E_{-H P}\right)$ for the heat pump system in dependence from the external ambient temperature $\left(t_{e}\right)$ from $-5^{\circ} \mathrm{C}$ to $+19^{\circ} \mathrm{C}$

\begin{tabular}{|c|c|c|c|c|c|c|c|c|}
\hline $\begin{array}{l}\boldsymbol{t}_{e} \\
{ }^{\circ} \mathrm{C}\end{array}$ & $\begin{array}{l}\tau \\
h\end{array}$ & $\begin{array}{r}\boldsymbol{Q}_{B, i} \\
\boldsymbol{k W h}\end{array}$ & $\begin{array}{c}\tau_{w, i-H P} \\
h\end{array}$ & $\begin{array}{c}E_{C, i} \\
k W h\end{array}$ & $\begin{array}{c}E_{F, i} \\
k W h\end{array}$ & $\begin{array}{c}E_{B, i-H P} \\
k W h\end{array}$ & $\begin{array}{c}\mathrm{COP}_{i} \\
-\end{array}$ & $\begin{array}{c}\text { Price }_{E-H P} \\
\epsilon\end{array}$ \\
\hline-5 & 15,0 & 2399,70 & 15,08 & 983,41 & 56,56 & 1039,97 & 2,31 & 121,55 \\
\hline$\ldots$ & $\ldots$ & $\ldots$ & $\ldots$ & $\ldots$ & $\ldots$ & $\ldots$ & $\ldots$ & $\ldots$ \\
\hline 0 & 52,3 & 6626,97 & 36,11 & 2253,53 & 135,43 & 2388,96 & 2,77 & 279,21 \\
\hline 1 & 36,0 & 4318,56 & 23,18 & 1638,41 & 86,93 & 1725,34 & 2,50 & 201,65 \\
\hline$\ldots$ & $\ldots$ & $\ldots$ & $\ldots$ & $\ldots$ & $\ldots$ & $\ldots$ & $\ldots$ & $\ldots$ \\
\hline 15 & 47,3 & 1258,12 & 4,97 & 359,60 & 18,63 & 378,23 & 3,33 & 44,21 \\
\hline 16 & 28,2 & 560,80 & 2 & 157,05 & 8,12 & 165,16 & 3,40 & 19,30 \\
\hline$\ldots$ & $\ldots$ & $\ldots$ & $\ldots$ & $\ldots$ & $\ldots$ & $\ldots$ & $\ldots$ & $\ldots$ \\
\hline 19 & 7,7 & 0,00 & 0 & 0,00 & 0,00 & 0,00 & 0,00 & 0,00 \\
\hline$\Sigma-5+15^{\circ} \mathrm{C}$ & - & 108741,4 & - & - & - & 38719,4 & - & 4525,34 \\
\hline$\Sigma-5+19^{\circ} \mathrm{C}$ & - & 109622,5 & - & - & - & 38976,5 & - & 4555,39 \\
\hline
\end{tabular}

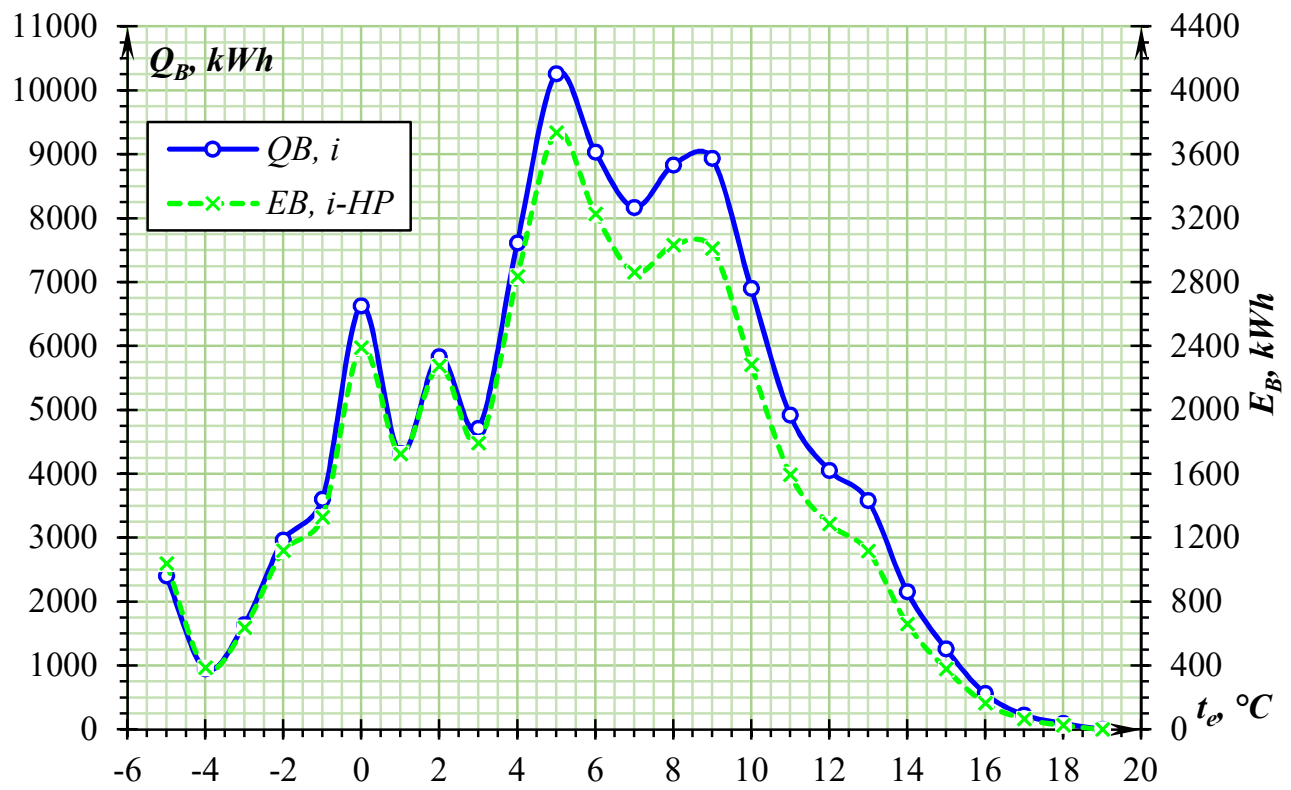

Fig.5. Heating energy of the building $\left(Q_{B, i}\right)$ and the electrical energy consumed $\left(E_{B, i-H P}\right)$ relative to an external ambient temperature $\left(t_{e}\right)$ in the range from $-5^{\circ} \mathrm{C}$ to $+19^{\circ} \mathrm{C}$

The seasonal efficiency of the heat pump operation in winter mode is determined by equation (6) for the coefficient of transformation in the temperature range of $-5^{\circ} \mathrm{C}$ to $+15^{\circ} \mathrm{C}$, resulting in $\mathrm{COP}_{-5^{\circ} \mathrm{C}+15^{\circ} \mathrm{C}}=2,808$, and at a temperature range of $-5^{\circ} \mathrm{C}$ to $+19^{\circ} \mathrm{C}$ of equation (7), there was obtained $C O P_{-5}{ }^{\circ} \mathrm{C}+19^{\circ} \mathrm{C}=2,813$. The results obtained justify the claim that the air-to-water heat pump system operates efficiently in heating mode at precisely measured external ambient temperature characteristic of the Black Sea climate zone. 
Figure 6 gives a relationship between the thermal energy of the building $\left(Q_{B, i}\right)$ and the external ambient temperature $\left(t_{e}\right)$ in the range of $-5^{\circ} \mathrm{C}$ to $+19^{\circ} \mathrm{C}$ with the value of the electrical energy (Price E-HP) $_{\text {. }}$

The value of the consumed electrical energy from the heat pump system for the winter heating season in the temperature range of $-5^{\circ} \mathrm{C}$ to $+15^{\circ} \mathrm{C}$ is $4525,34 €$ and in the temperature range of $-5^{\circ} \mathrm{C}$ to $+19^{\circ} \mathrm{C}$ is $4555,39 €$ and it can be said that the system works economically.

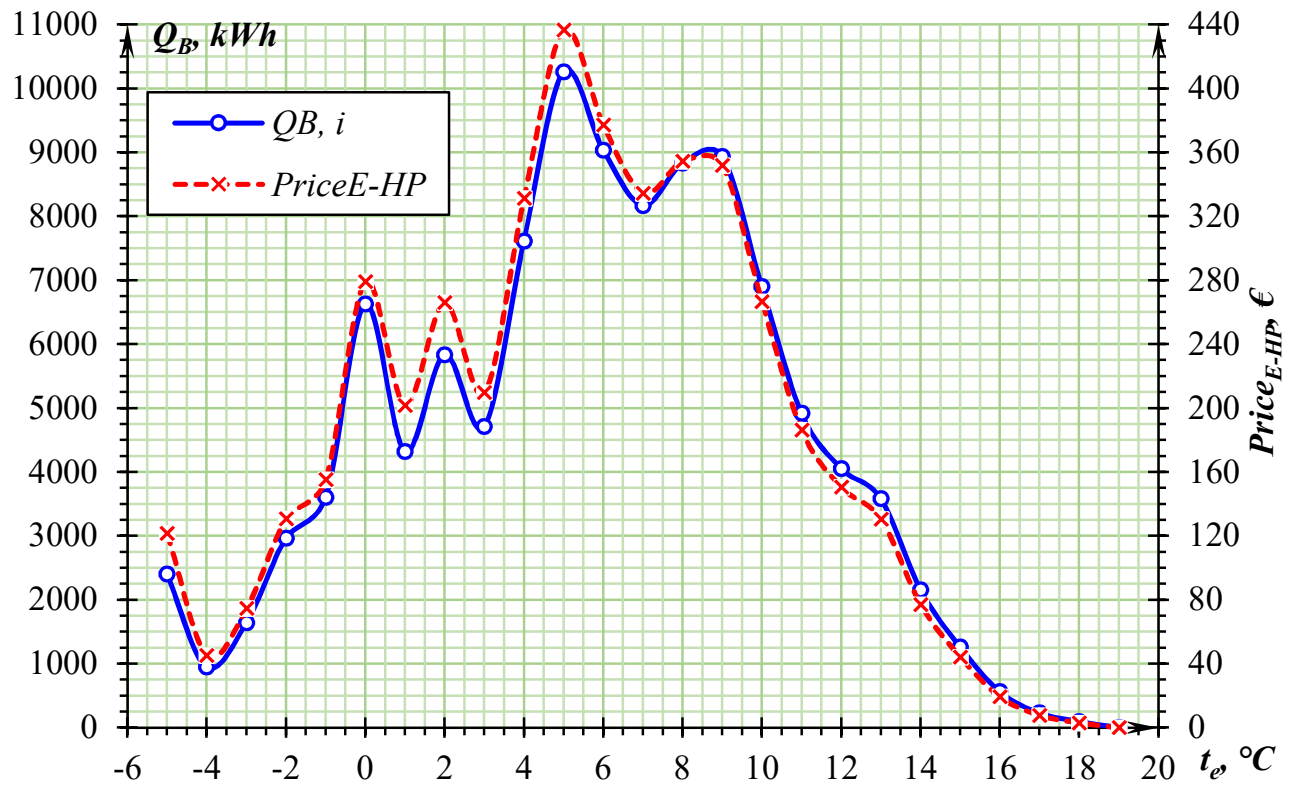

Fig. 6. Building thermal energy $\left(Q_{B, i}\right)$ and value of the electrical energy $\left(\right.$ Price $\left._{E-H P}\right)$ relative to an external ambient temperature $\left(t_{e}\right)$ in the range from $-5^{\circ} \mathrm{C}$ to $+19^{\circ} \mathrm{C}$

\section{Conclusion}

The experimental results for the seasonal efficiency of the heating air-water heating system in the two temperature ranges from $-5^{\circ} \mathrm{C}$ to $+15^{\circ} \mathrm{C}$ and from $-5^{\circ} \mathrm{C}$ to $+19^{\circ} \mathrm{C}$ are $\mathrm{COP}_{-5^{\circ} \mathrm{C}+15^{\circ} \mathrm{C}}=2,808$ and $\mathrm{COP}_{-5^{\circ} \mathrm{C}+19^{\circ} \mathrm{C}}=2,813$ and warranted the claim that the air-towater heat pump system operates efficiently in heating mode at the precisely measured external ambient temperature typical of the Black Sea climate zone. The economic analysis shows that the costs for the consumed electrical energy from the heat pump system for the winter heating season at the considered temperature intervals are extremely effective. The results of the study can be used both in the design of air-to-water heat pump systems and in the search for energy efficiency buildings.

\section{References}

1. G. Valtchev, N. Kalojanov, V. Rasheva, M. Minchev, S. Tasheva. Analysis of results after implementation of energy saving measures in public buildings, Bulgarian Chemical Communications, 48, 283 - 289 (2016)

2. V. Rasheva, V. Kamburova, M. Velikanov. Results from an Energy Audit of a Jointstock Company "Medica AD", Proceedings at 7th International Conference on TE-RE$R D, 129-134$ (2018) 
3. N. Penkova, N. Harryzanov, Analysis and optimization of the temperature stratification at thermal energy storage tank, Proceedings at 5th International Conference on Energy and Sustainability, 469-477 (2014)

4. Z. D. Kolev, S. Y. Kadirova, T. R. Nenov, Research of reversible heat pump installation for greenhouse heating, INMATEH - Agricultural Engineering, 2, 77-84 (2017)

5. X. Wang, C. Zhang, Z. Zhang, B. Sun, Experimental research on performance of airsource heat pumps, $H V \& A C, \mathbf{4 4}, 119-123$ (2014)

6. Z. Zeng, J. Wu, X. Wei, Experimental Study and Thermal Performance Analysis of Air - source Heat Pump Direct Floor Radiant Heating System, Acta Energiae Solaris Sinica, 8, 1151-1157 (2011)

7. D. Rusev, A. Kirov, P. Zlateva, N. Trizlova, D. Genov, Analysis of the operation of airwater heat pump unit in winter mode, Proceedings of the annual symposium with international participation SISOM \& ACOUSTICS, 203-208 (2012)

8. National Institute of Meteorology and Hydrology-Varna, http://www.stringmeteo.com (2019)

9. Energo pro, https://www.energo-pro.bg (2019)

10. Bulgarian National Bank, http://www.bnb.bg (2019)

11. Catalog of Wesper, http://www.wesper.co.uk (2019) 